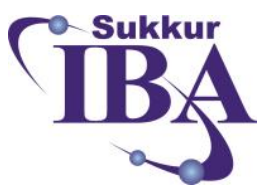

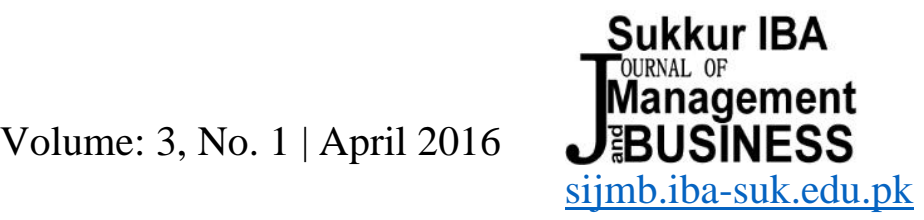

\title{
Sustainable Soil Management Practices: Adoption and Its Impact on Farm Income in Ramechhap District, Nepal
}

\author{
Rishi Ram Kattel ${ }^{1}$ \\ Assistant Professor, Department of Agricultural Economics and Agribusiness \\ Management, Agriculture and Forestry University, Rampur, Chitwan, Nepal
}

Suraj Acharya

Department of Agricultural Economics and Agribusiness Management, Agriculture and Forestry University, Rampur, Chitwan, Nepal

\begin{abstract}
This study was carried out to assess the impact of sustainable soil management (SSM) practices in relation to technology adoption and farm income in Ramechhap district of Nepal in 2015. Total 120 sample households were taken (60 SSM practices adopters and 60 non-adopters) using random sampling technique. Primary data were collected through face-to-face interview, focus group discussion, direct observation and key informant interview to gauge the impact using with-without SSM project intervention approach. Descriptive statistics along with independent t-test, chi square test, Probit and income function multi-regression models were used for data analysis. From the costbenefit analysis, in tomato production, all the variables were found to be significantly different except cost of planting materials. The gross margin, gross income and B: C ratio were also found to be significantly different in tomato production by SSM practices adoption. In beans, potato and cauliflower production, most of the variables were found to be significantly different. The results revealed that, farm income was higher in adopters by significant margin whereas the income from services and remittance was higher in non-adopters than adopters. Probit model revealed that type of family and trainings received were found statistically and positively significant on SSM practices adoption whereas education of household head had negative impact. Income function multi-regression model showed that SSM adoption, male of the respondent, education of the household head and farm size have positively significant on farm income whereas nuclear family type was negatively determinate on farm income. Among the variables, SSM practices adoption was major determinate factor on farm income. If farmer adopted SSM practices, farm income would be about 198 percent higher than among non-adopters. SSM technology has identified an environmentally friendly and improved rural farmers' income in a sustainable manner in Nepal.
\end{abstract}

Keywords: SSM practices, Technology Adoption, Farm income, Nepal.

https://doi.org/10.30537/sijmb.v3i1.136

1 rishikattel@gmail.com

SIJMB | E-ISSN: 2410-1885; P-ISSN: 2313-1217 @ 201633 Sukkur Institute of Business Administration - All rights reserved 
Rishi Ram Kattel \& Suraj Acharya / Sustainable Soil Management Practices: Adoption and Its Impact on Farm Income in Ramechhap District, Nepal

\section{Introduction}

Nepal has a total area, production and productivity of the vegetables as 246,392 hectares, 3,301,684 metric tons (MT) and 13.40 MT/ha respectively. The contribution of vegetables in AGDP is 20.74 percent Diary (2014). The ecological diversity and the favorable condition to produce different crops in different region have provided a lot of scope and opportunity to the farmers of the country. In recent times, demand for the healthy vegetable products and the increased nutritional knowledge of the people have also provided further scope for the commercial vegetable production. Off-season vegetable farming is one of the methods of commercialization. Off- season vegetable farming refers to the production of vegetables before or after their normal season of production by using different agro climatic conditions, adjusting the planting time, selecting and improving the varieties, and/or creating a controlled environment. AEC (2006) reported that off-season vegetable farming is one of the potential sources of income and reliable means for the reduction of poverty and malnutrition persisting over the hills of Nepal. Because of comparative advantage through topography Prasain (2011) farmers from hills have greater value to produce off-season vegetables during rainy season when prices observed higher in Terai areas and Indian boarder cities.

Sustainable Soil Management Program (SSMP) targets improvements in soil fertility and productivity in the mid hills of Nepal with the aim of increasing food production, food security and farm income. SSM practices includes improved farm yard manure, improved cattle sheds and urine use, legume integration, use of bio-pesticide integrated plant nutrient systems, fodder promotion for livestock, SSM-based vegetable production etc.

In the recent years there is increasing consciousness on the quality of the food items that the peoples are consuming. So farmers are moving towards the commercialization of vegetable farming. In the long run excessive application of chemical fertilizers and pesticides is causing the partial desertification in many pocket areas of Ramechhap district. There is ever increasing input supply and decreasing trend of productivity so that threat the livelihood of farmers in agriculture (NPG, 2003). Thus commercial vegetable farming and increasing demand of healthy vegetables in the market has created the study environment for SSM based vegetable production economics.

This study focused on identification of sustainable soil management based vegetable production along with their economic feasibility. The finding of this research answers the issues of SSM based production, Marginal output from it, and types of SSM practices preferred by farmers. Furthermore, this study also answers which SSM practice is economically profitable and perception of farmers towards SSM practices is identified. This study helps the farmers to rethink about production activities they are doing and for development workers about which activities are to be promoted. Also in case of researchers the finding of this study helps to identify the strengths, weaknesses, opportunities and the threats of particular cultivation practices.

SIJMB | P-ISSN: 2313-1217 E-ISSN: 2410-1885 @ 201634 Sukkur Institute of Business Administration V.3, No.1 | Apr 16 
Since Ramechap is one of the hilly districts of Nepal, the production techniques have not been well developed and the production and productivity are low. The problem of the food security is significant problem in the region. The production of the district is not sufficient. Similarly, the problem of fertilizer availability and its continuous going sky touching prices, and considering of soil health on order to sustain the soil production farmers have to use farm yard manure. SSM based agriculture is cost effective, affordable and does not require expensive technical investment but provides more employment opportunity. It is a viable solution to preventing global hunger by providing comparatively higher yields from low input agriculture in food deficit regions (Leu, 2004).

The overall objective of this research was to assess the impact of sustainable soil management practices in relation to technology adoption and farm income in Ramechhap district of Nepal.

Specific objectives of this study were as followed:

1. To investigate the factor determining adoption of SSM practices considering vegetable growers.

2. To assess impact of SSM technology on farm income in relation to vegetable production.

3. To analyze strengths, weaknesses, opportunities and threats of SSM practices focusing to adoption and its consequences.

\section{Literature Review}

Sustainable agriculture is as a set of management strategies addressing the main societal concerns about food quality or environment protection (Francis, Sander, \& Martin, 1987). In other words, agricultural systems are considered to be sustainable if they sustain themselves over a long period of time, that is, if they are economically viable, environmentally safe and socially fair.

As farmers increasingly confront declining per capita return arisen from miniaturizing land holdings caused by steadily growing population, they are required to make additional efforts to increase agricultural production. They will thus adopt an agricultural system only when it is both economically and environmentally suitable (Rasul \& Thapa, 2003). The adoption of sustainable agriculture strategies/technologies has received frequent attention in recent years, both by producers and consumers. Despite economic and noneconomic disadvantages of conventional agriculture, farmers have been slow to adopt these practices, and adoption appears to vary widely by region and crops (Musser et al., 1986). In recent years organic agriculture has been adopted by most of the farmers as a means of sustainable agriculture.

There are, as with sustainable agriculture, a variety of definitions of organic farming Mannion (1995) refers to it as a holistic view of agriculture that aims to reflect the

SIJMB | P-ISSN: 2313-1217 E-ISSN: 2410-1885 @ 201635 Sukkur Institute of Business Administration V.3, No.1 | Apr 16 
profound interrelationship that exists between farm biota, its production and the overall environment. Scofield (1986) stresses that organic farming does not simply refer to the use of living materials, but emphasizes the concept of 'wholeness', implying the "systematic connection or co-ordination of parts in one whole". Organic production is feasible virtually throughout the country, without major adjustments to traditional production methods. Organic seed production, vegetable production, fruits production etc. could be made easy under such a diverse topography, soil and climatic situations. Thanks to physical conditions that made this possibility easy. Direct market linkage with India could be other strength. Organic production has been started by the farmers themselves without government intervention.

Farming in the mid-hills of Nepal is characterized by a close relationship between crop production, livestock and forestry, with trees and crops providing fodder and bedding materials for livestock, which in turn provide draft power and manure. Soil fertility is largely maintained by the application of compost and manure, but in recent years a decline in soil fertility has been reported (Shrestha et al., 2000). It is a well-established that soil fertility in Nepal is declining in recent years, increased use of high-yielding crop varieties in intensive cropping systems have led to an increased demand for nutrients. The locally available sources of nutrients, mainly farm-yard manure (FYM), compost, and biologically fixed nitrogen are not sufficient to meet the needs. Farmers in accessible areas have started to use chemical fertilizers as a means of coping with the reduced nutrient availability. However, imbalanced use, and inappropriate timing and methods, of fertilizer application have resulted in adverse effects on soil productivity, on sustainability, and on environmental quality (Joshi \& Ghimire, 1996); (Sthapit et al., 1988); (Subedi et al., 1989); (Tamang, 1992).

The problems of soil quality deterioration and fertility decline are prevalent throughout the world but they are especially serious in the heavily populated, under-developed, and ecologically fragile areas of the (Nepal Harden, 2001). Comparative profitability of conventional or inorganic and SSM based production practices varies due to wide range of production methods used in different regions and with different crops, and because of the variable organic price premiums (Cook, Norris, \& Pickel, 1989). The profitability of SSM based production method usually depends on price premiums. Scialabba (2006) found that the productivity of organically grown carrot yield is found higher (27.9 MT/ha) than that of inorganically grown carrot (26.30 ton/ha). In some situations SSM based growers may be less vulnerable to natural and economic risks than conventional farmers since their systems are usually more diversified (Olson, Langley, \& Heady, 1982). SSMP and the SSM practices that are promoted are increasingly relevant and important in the struggle for mid-hill food availability and livelihood sustainability (SSMP, 2009).

The periodic application of farmyard manure (FYM) has been reported to improve many physio-chemical properties of the soil, viz., improvement in soil structure,

SIJMB | P-ISSN: 2313-1217 E-ISSN: 2410-1885 @ 201636 Sukkur Institute of Business Administration V.3, No.1 | Apr 16 
increased water-holding capacity, and enhanced biological activity (Maheswarappa, Nanjappa, \& Hegde, 2015); (Schjønning, Christensen, \& Carstensen, 1994). Farmyard manure is also a good reservoir of nutrients, adding to fertility build up in the soil. It is known to improve soil productivity on a sustainable basis over a long period (Flaig, 1975). Legumes have long been advocated as the missing ingredient for conserving soil resources in subsistence agriculture and Legume intensification is often advocated to improve the productivity and sustainability of cereal-based cropping systems in developing countries (Cromwell \& Winpenny, 1993); (Thapa, 1996).

The use of plants, plant material or crude plant extracts (botanical insecticides) for the protection of crops and stored products from insect pests is probably as old as crop protection itself. Indeed, prior to the development and commercial success of synthetic insecticides beginning in the 1940s, botanical insecticides were major weapons in the farmer's arsenal against crop pests (Thacker, 2002).

Rogers (2003) defined the adoption process as "the mental process an individual passes from first hearing about an innovation to final adoption". Several adoption and diffusion processes may occur simultaneously. Mann (1978) pointed out such adoption processes may follow specific sequential patterns. Constraints to the rapid adoption of innovations involve factors such as the lack of credit, limited access to information, aversion to risk, inadequate farm size, inadequate incentives associated with farm tenure arrangements, insufficient human capital (Feder, Just, \& Zilbermanm, 1985).

\section{Research Methodology}

\subsection{Conceptual Framework}

This study mainly focused on the impact and economic significance of sustainable soil management practices based vegetable production. This study also examined the level of adoption and the associated factors related with the adoption of SSM practices. Age, gender, economically active members in a family, education level, farm size, farm income, household head, training received and membership in farming groups/ organizations, etc. are the socio-economic factors that govern the adoption of livelihood strategies. Access to assets (natural, physical, social, human, financial, etc.) by the farmers leads them to change the livelihood strategy from conventional farming to commercial/sustainable farming through the continuous adoption of sustainable soil management practices. Problems like decline in soil fertility, expensive inorganic inputs, timely unavailability of inorganic fertilizers, environment pollution, pesticides hazards, unhealthy foods creates environment favorable for the adoption of SSM practices. When it shows positive impacts (economic, social, environmental, institutional, etc.) on living it gives livelihood outcomes like improved soil health, higher productivity, higher net farm income, improved food safety, quality and food security, more self-sufficiency, sustainability of crop production, better functioning social network and groups, ecological balanced, sustainable use of natural resources,

SIJMB | P-ISSN: 2313-1217 E-ISSN: 2410-1885 @ 201637 Sukkur Institute of Business Administration V.3, No.1 | Apr 16 
Rishi Ram Kattel \& Suraj Acharya / Sustainable Soil Management Practices: Adoption and Its Impact on Farm Income in Ramechhap District, Nepal

Reduced dependence on costly inputs and credits. This ultimately leads to the better health increased household income and better welfare of the people (Figure 1).

\section{Figure 1: Conceptual framework adopted for the study (Own illustrations)}

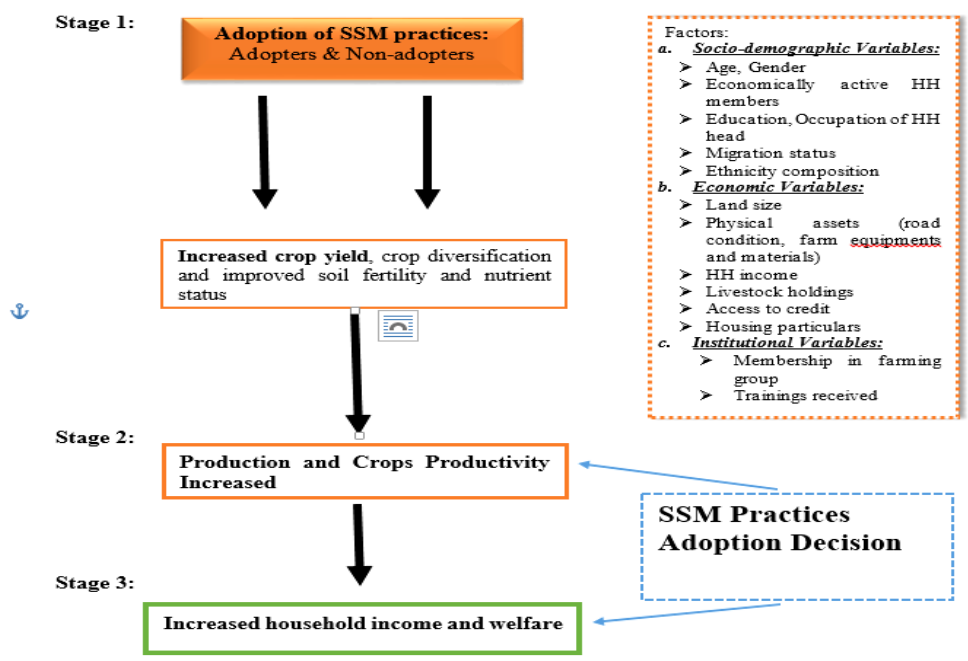

Figure 2: Map of Ramechhap district showing research site (DADO, 2010)

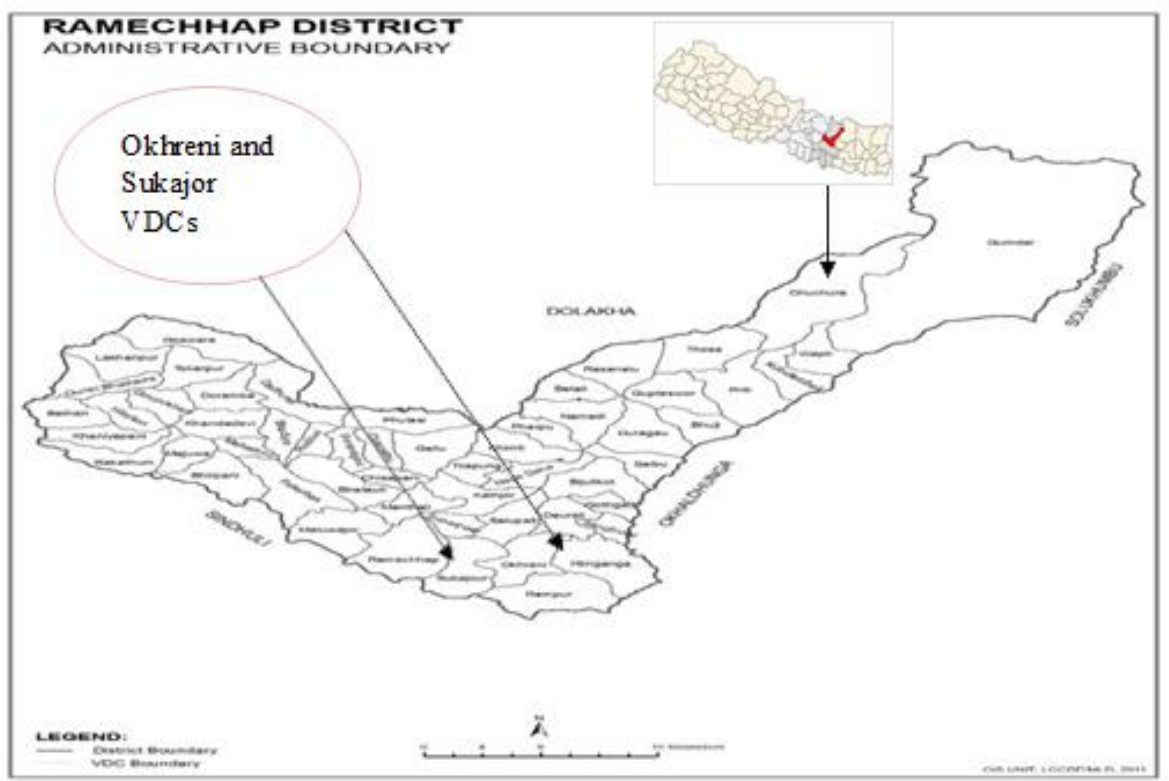

SIJMB | P-ISSN: 2313-1217 E-ISSN: 2410-1885 @ 201638 Sukkur Institute of Business Administration V.3, No.1 | Apr 16 


\section{Selection of the study area}

The pocket areas within the district were selected purposively based on area coverage and production of vegetables as well as the SSMP implemented areas. Based on these criteria, two Village Development Committees (VDCs) namely, Okhreni and Sukajor were selected from Ramechhap District where SSM program had successfully launched for about five years. Site of the study area is presented in Figure 2.

\section{Sample and sample selection procedure}

By using sampling frame, a simple random sampling technique was used to collect necessary information from both VDCs. The procedure was comprehensive and representative of the whole population. Total 120 samples were taken using purposive random sampling technique. Total 60 samples were taken from Okhreni VDC and remaining 60 samples from Sukajor VDC in Ramechhap district.

\section{Methods of data collection}

During this study, both the primary and secondary data were collected. The methodologies consisted of field survey, review of previous studies, and interviews with leading vegetable producers, and also direct observation of the farmer's field.

\section{- Preliminary Survey}

Prior to the field survey, a field visit was carried out to the study area in 2014. The main objective of the visit was to become familiar with geographical as well as other different features of the study area.

\section{- Preparation of Interview Schedule and Pre-testing}

After preliminary field visit, interview schedule was prepared for the field survey to collect primary information from the farmers. Pre-testing of interview schedule was done before the field survey to the few of the respondents. The finalization of the interview schedule was done by giving due consideration to the points where we felt there should be some corrections during the pre-testing.

\section{- Focus Group Discussion (FGD) and Key Informant Survey (KIS)}

FGD and KIS was done in both the VDCs involving the VDC/ward representatives, female farmers of different ethnic groups, school teachers, leader farmers and key informer from the VDC.

\section{- Household Survey}

Field survey was conducted in both selected VDCs randomly as 60 household from each VDC making total respondents 120. Regular checking and validation of the information were done immediately after filling the interview schedule.

SIJMB | P-ISSN: 2313-1217 E-ISSN: 2410-1885 @ 201639 Sukkur Institute of Business Administration V.3, No.1 | Apr 16 
Rishi Ram Kattel \& Suraj Acharya / Sustainable Soil Management Practices: Adoption and Its Impact on Farm Income in Ramechhap District, Nepal

\section{- Methodological approach of impact evaluation}

With without approach was used for the impact study of sustainable soil management practice. For the impact assessment pair $t$ test was used to test the impact of adoption of these practices on area and production of the different crops.

\section{Methods of Data Analysis}

The collected information were tabulated, coded and fed into the computer for analysis. Data were fed to Microsoft excel and analysis was done by using Statistical Package for Social Sciences (SPSS version 23.0) and STATA (version 13.0). Different statistical tools like mean, frequency, chi- square test, t-test, F-test, standard deviation, Ordinary Least Square Technique of Multiple Regression and the Likert scale technique as well as correlation study were done to derive inference needed.

\section{- Model specification}

Profit model for adoption decision and income function model for impact of farm income were used in econometric analysis. The Probit model specified in this study to analyze farmer's adoption of sustainable soil management practices in relation to farm income was expressed as follows:

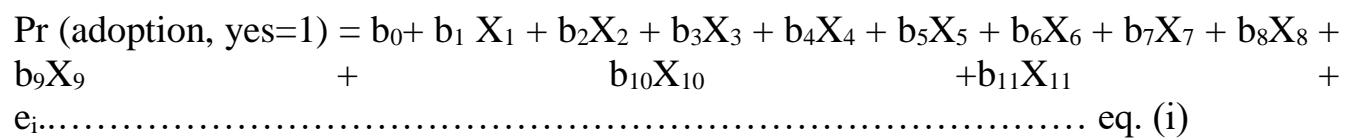

Farm income $\left(Y_{i}\right)=b_{0}+b_{1} X_{1}+b_{2} X_{2}+b_{3} Y_{i}+b_{4} X_{4}+b_{5} X_{5}+b_{6} X_{6}+b_{7} X_{7}+b_{8} X_{8}+b_{9} X_{9}$ $+b_{10} X_{10}+b_{11} X_{11}+b_{12} S S M \quad$ Adoption $_{i}+$

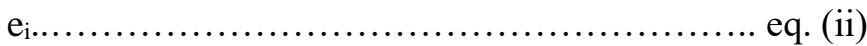

Where,

$\operatorname{Pr}($ adoption, yes $=1)=$ Probability score of adopting SSM practices (at least two SSM practices $=1,0=$ Otherwise)

$\mathrm{X}_{1}=$ Age of HH head (Years)

$\mathrm{X}_{2}=$ Gender of HH head (Dummy: Male $=1,0=$ Female)

$\mathrm{X}_{3}=$ Ethnicity/Social background of the family (Higher caste $=1,0=$ Otherwise) ${ }^{2}$

$\mathrm{X}_{4}=$ Family type (Nuclear $=1,0=$ Joint $)$

$\mathrm{X}_{5}=$ Educated family members (Numbers)

$\mathrm{X}_{6}=$ No of schooling years of $\mathrm{HH}$ head (Numbers)

$\mathrm{X}_{7}=$ Economically Active Family members (Numbers)

$\mathrm{X}_{8}=$ Migration (Household member migrated to aboard $=1,0=$ Otherwise)

$\mathrm{X}_{9}=$ Farm size $(\mathrm{ha})$

$\mathrm{X}_{10}=$ Trainings (Training received $=1,0=$ Otherwise)

${ }^{2}$ Brahmin and Chhetri are Higher castes in Nepal

SIJMB | P-ISSN: 2313-1217 E-ISSN: 2410-1885 @ 201640 Sukkur Institute of Business Administration V.3, No.1 | Apr 16 
Rishi Ram Kattel \& Suraj Acharya / Sustainable Soil Management Practices: Adoption and Its Impact on Farm Income in Ramechhap District, Nepal

$\mathrm{X}_{11}=$ Membership of other farming groups/organizations (Membership $=1$, $0=$ Otherwise)

$\mathrm{SSM} \mathrm{Adoption}_{\mathrm{i}}$ If farmer adopted at least two or more SSM practices=1, 0=Otherwise Farm Income $\left(\mathrm{Y}_{\mathrm{i}}\right)=$ Farm income from agriculture and livestock sectors (Nepalese Rupees in Natural Log)

$\mathrm{b}_{1}, \mathrm{~b}_{2 \ldots} \ldots \mathrm{b}_{11}=$ Probit coefficient $; \mathrm{b}_{0}=$ Regression coefficient

\section{Results and Discussion}

\section{Socio demographic characteristics of sampled households in the study area}

The average number of educated household member was 3.49 whereas that of adopters (3.85 years) was slightly higher than that of non-adopters (3.13 years). The average family size was 7.38 whereas that of adopters was found to be 6.48 and that of nonadopters was 8.28. Average family size in the study area was found greater than the district average of 5.15 (DADO, 2010) and national average of 4.7 (CBS, 2011). The average number of economically active household members was found to be 4.84 and the average of adopters 4.27 was higher than that of non-adopters 5.23 (Table 1).

Table 1: Socio-demographic factors of the households by SSM practices adoption

\begin{tabular}{|c|c|c|c|c|c|}
\hline Socio-demographic variables & $\begin{array}{l}\text { Total } \\
(\mathrm{N}=120)\end{array}$ & $\begin{array}{l}\text { Adopters } \\
\underline{(n=60)}\end{array}$ & $\begin{array}{l}\begin{array}{l}\text { Non- } \\
\text { adopters } \\
(\mathrm{n}=60)\end{array} \\
\end{array}$ & $\begin{array}{l}\frac{\text { Mean }}{\text { differe }} \\
\text { nce }\end{array}$ & t-value \\
\hline Age of household $(\mathrm{HH})$ head & 48.1(12.36) & $47.43(12.94)$ & $48.76(11.83)$ & -1.33 & -0.589 \\
\hline Years of schooling of $\mathrm{HH}$ head & $2.98(2.53)$ & $3.03(2.19)$ & $2.92(2.85)$ & 0.12 & 0.251 \\
\hline Agriculture engaged $\mathrm{HH}$ members & $4.05(1.57)$ & $3.88(1.34)$ & $4.22(1.76)$ & -0.33 & -1.164 \\
\hline Educated HH members & $3.49(1.32)$ & $3.85(1.54)$ & $3.13(0.92)$ & 0.72 & $3.07 * * *$ \\
\hline Family size & $7.38(3.01)$ & $6.48(1.24)$ & $8.28(1.28)$ & -1.8 & $3.416^{* * *}$ \\
\hline $\begin{array}{lll}\text { Economically active } & \mathrm{HH} \\
\text { members(age group } 15-60) & \end{array}$ & $4.85(2.03)$ & $4.27(0.65)$ & $5.43(0.71)$ & -1.17 & - \\
\hline $\begin{array}{l}\text { Elderly HH members(age group } \\
\text { above } 60 \text { ) }\end{array}$ & $0.54(0.68)$ & $0.47(2.41)$ & $0.62(3.28)$ & -0.15 & -1.202 \\
\hline Dependency ratio in $\mathrm{HH}$ & $0.33(0.16)$ & $0.33(0.18)$ & $0.33(0.13)$ & 0 & 0.036 \\
\hline Migrants number in $\mathrm{HH}$ & $1.38(0.73)$ & $1.29(0.68)$ & $1.44(0.76)$ & -0.15 & -0.63 \\
\hline
\end{tabular}

\section{Land holdings}

The average land holding of the household was found to be 13.39 Ropani $^{3}$ which is lesser than the national average of 0.8 hectare. From the study it was found that 45.80 percent of the household had small farm size (less than 10 Ropani), 41.70 percent had medium farm size (10-20 Ropani) and only 12.50 percent had large farm size (more than 20 Ropani). Table 2 presents the land holding size of the sampled households in the study area.

31 hectare $=19.66$ Ropani

SIJMB | P-ISSN: 2313-1217 E-ISSN: 2410-1885 @ 201641 Sukkur Institute of Business Administration V.3, No.1 | Apr 16 
Rishi Ram Kattel \& Suraj Acharya / Sustainable Soil Management Practices: Adoption and Its Impact on Farm Income in Ramechhap District, Nepal

Table 2: Land holding size of the sampled households in the study area

\begin{tabular}{llll}
\hline Land holding (Ropani) & \multicolumn{1}{c}{ Total $(\mathrm{N}=120)$} & Adopters $(\mathrm{n}=60)$ & Non-adopters $(\mathrm{n}=60)$ \\
\hline Less than 10 (small) & $55(45.8)$ & $23(38.3)$ & $32(53.3)$ \\
10 to 20 (medium) & $50(41.7)$ & $27(45.0)$ & $23(38.3)$ \\
More than 20 (large) & $15(12.5)$ & $10(16.7)$ & $5(8.4)$
\end{tabular}

Note: Figures in Parentheses indicate Percent

\section{Livestock holding}

All the farm families were engaged in livestock farming. Average livestock holding was 6.38 $\mathrm{LSU}^{4}$ with maximum 19.46 LSU and minimum of $1.92 \mathrm{LSU}$ in entire site. The average, maximum and minimum value of LSU was found greater in adopters than that of non-adopters (Table 3).

Table 3: Livestock holdings by SSM practices adopters and non-adopters

\begin{tabular}{llll}
\hline & \multicolumn{2}{c}{ Livestock standard unit } \\
\cline { 2 - 4 } & $\underline{\text { Mean }}$ & $\underline{\text { Maximum }}$ & Minimum \\
\hline Non adopter & 6.14 & 12.60 & 1.92 \\
Adopter & 6.62 & 19.46 & 2.00 \\
Mean Difference & 0.48 & 6.86 & 0.08 \\
Total & 6.38 & 19.46 & 1.92 \\
\hline
\end{tabular}

\section{Different organizations/groups membership by household members}

Majority of household were found participating in the organizations like community forest user group and saving and credit group. 91.7 percent of the household members were found to be participated in community forest user groups followed by 78.3 percent of household members in saving and credit groups (Figure 3).

Figure 3: Membership of the household members in different groups Membership of the hh members in different groups

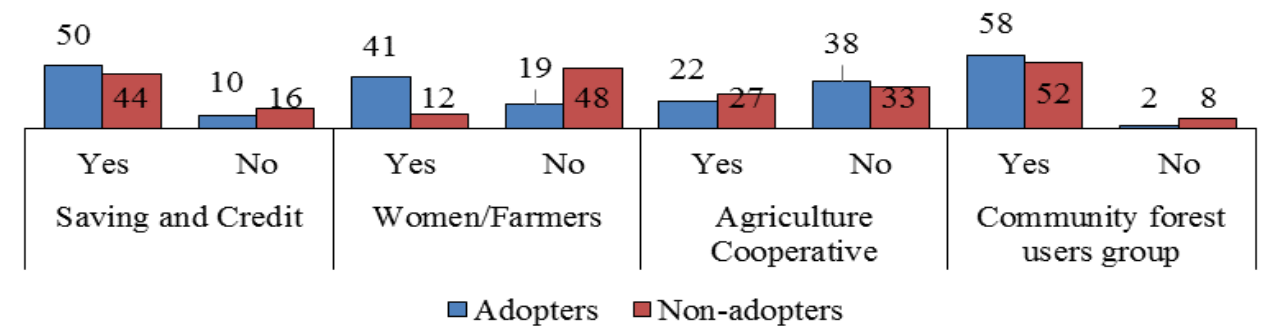

${ }^{4}$ LSU is Livestock Standard Unit (based on cattle equivalent: 1 cow/cattle= 10 goats/lambs= 4 pigs and $=143$ chicken/ducks)

SIJMB | P-ISSN: 2313-1217 E-ISSN: 2410-1885 (C) 2016 42 Sukkur Institute of Business Administration V.3, No.1 | Apr 16 
Rishi Ram Kattel \& Suraj Acharya / Sustainable Soil Management Practices: Adoption and Its Impact on Farm Income in Ramechhap District, Nepal

Comparative economics of tomato cultivation in between adopters and nonadopters of SSM practices

Area of tomato under cultivation was found significant difference between adopters and non-adopters of SSM Practices. Hired Labor cost was found significant difference as there was decrease in cost by Rs. 796. Other cost items like total manure cost, cost of chemical fertilizers, cost of pesticides, total cost of production and average cost were found significant difference at 1 percent and 5 percent level of significance, respectively. Likewise, per ropani cost of chemical fertilizers, cost of pesticides and total cost of cultivation were found decreased by NRs. 367, 321 and 3598, respectively. The average cost (NRs/kg) was found significantly lower after practicing SSM by about NRs. 9 than non-adopters (Table 4).

It was found that Net income (Rs/ropani), Gross income (Rs/ropani), and B: C ratio was found significant difference between adopters and non-adopters of SSM Practices. Table 5 presents the comparative return of tomato cultivation by SSM adoption.

Table 4: Comparative cost of tomato cultivation by SSM adoption

\begin{tabular}{|c|c|c|c|c|c|}
\hline & $\begin{array}{l}\text { Total } \\
(\mathrm{N}=120) \\
\end{array}$ & $\begin{array}{l}\text { Adopters } \\
\underline{(\mathrm{n}=60)}\end{array}$ & $\begin{array}{l}\text { Non-adopters } \\
\underline{(\mathrm{n}=60)}\end{array}$ & $\begin{array}{l}\text { Mean } \\
\text { difference }\end{array}$ & $\underline{\mathrm{T} \text { value }}$ \\
\hline Area (ropani) & 0.66 & 0.83 & 0.49 & 0.33 & $3.19 * * *$ \\
\hline Hired labour cost & 503.25 & 203.13 & 1000.00 & -796.88 & $-3.34 * * *$ \\
\hline Cost of planting materials & 593.18 & 581.77 & 612.07 & -30.30 & -1.53 \\
\hline Cost of chemical fertilizers & 498.21 & 359.64 & 727.59 & -367.95 & $-8.54 * * *$ \\
\hline Cost of manure & 1543.55 & 1623.33 & 1411.49 & 211.84 & $2.26 * *$ \\
\hline Cost of pesticides & 189.33 & 68.23 & 389.77 & -321.54 & $-5.45 * * *$ \\
\hline Packing and marketing cost & 717.48 & 908.33 & 401.60 & 506.74 & $9.16^{* * *}$ \\
\hline Total cultivation cost & 6122.09 & 7921.13 & 4323.05 & 3598.08 & $4.14 * * *$ \\
\hline Average cost & 9.00 & 5.53 & 14.75 & -9.22 & $-6.24 * * *$ \\
\hline
\end{tabular}

Note: $* * *$ And $* *$ indicates significant difference at $1 \%$ and $5 \%$ levels, respectively

Table 5: Comparative return of tomato cultivation by SSM adoption

\begin{tabular}{|c|c|c|c|c|c|}
\hline Variable & $\begin{array}{l}\text { Total } \\
\underline{(\mathrm{N}=120)}\end{array}$ & $\frac{\text { Adopters }}{\underline{(\mathrm{n}=60)}}$ & $\begin{array}{l}\begin{array}{l}\text { Non- } \\
\text { adopters } \\
\text { (n=60) }\end{array} \\
\end{array}$ & $\begin{array}{l}\text { Mean } \\
\underline{\text { difference }}\end{array}$ & $\underline{\mathrm{T} \text { value }}$ \\
\hline Net income (NRs/ropani) & 30429.42 & 48175 & 12683.83 & 35491.17 & $6.14 * * *$ \\
\hline Gross income (NRs/ropani) & 32516.67 & 51091.67 & 13941.67 & 37150 & $5.95 * * *$ \\
\hline $\mathrm{B}: \mathrm{C}$ ratio & 4.83 & 5.97 & 2.95 & 3.02 & $5.93 * * *$ \\
\hline
\end{tabular}

Notes: $* * *$ indicates significant difference at $1 \%$ level 
Rishi Ram Kattel \& Suraj Acharya / Sustainable Soil Management Practices: Adoption and Its Impact on Farm Income in Ramechhap District, Nepal

Comparison of household incomes in between adopters and non-adopters of SSM practices

On farm income and off farm income and total household income was found significant after the adoption of SSM practices. In total, the share of farm income from vegetables and livestock were found significantly different at 1 percent level. Similarly the income from services was significantly different at 1 percent level after the adoption of SSM practices (Table 6).

Table 6: Annual income from various sources by SSM practices adoption

\begin{tabular}{|c|c|c|c|c|c|}
\hline $\begin{array}{l}\text { Income in } \\
\text { the HH }\end{array}$ & $\underline{\text { Total }(\mathrm{N}=120)}$ & $\frac{\text { Adopter }}{\underline{(\mathrm{n}=60)}}$ & $\begin{array}{l}\text { Non-adopter } \\
\underline{(\mathrm{n}=60)}\end{array}$ & $\begin{array}{l}\frac{\text { Mean }}{\text { differen }} \\
\text { ce }\end{array}$ & $\underline{\text { T-value }}$ \\
\hline Cereals & $0.01(0.09)$ & $0.00(0.00)$ & $0.02(0.13)$ & $\overline{-0.02}$ & -1.00 \\
\hline Vegetable & 87133(90169) & 154267(78119) & $20000(33609)$ & 134267 & $12.23 * * *$ \\
\hline Livestock & $27525(21402)$ & $34600(25822)$ & $20450(12462)$ & 14150 & $3.82 * * *$ \\
\hline Business & $5583(34685)$ & $0(0)$ & 11167(48611) & -11167 & $-1.78^{*}$ \\
\hline Services & $38500(97610)$ & $11583(68886)$ & $65417(114008)$ & -53833 & $-3.13 * * *$ \\
\hline Wage labor & $11379(28143)$ & $9100(24190)$ & $13658(31652)$ & -4558 & -0.89 \\
\hline Remittance & $81367(176094)$ & 60233(109123) & $102500(222997)$ & -42267 & -1.32 \\
\hline
\end{tabular}

Notes: Figures in parentheses indicate standard deviation. *** And * indicates significant difference at $1 \%$ and $10 \%$ levels respectively

\section{Reasons for adopting sustainable soil management practices}

It was observed that 98.3 percent of the sampled farmers expressed the reason of adopting sustainable soil management practice was for sustainable production. 93.3 percent of household opinion on adoption was due to healthy soil and environment. Higher yield was the main reason for all of the SSMP adopting households whereas the higher price was the reason for 78.3 percent of the adopters (Table 7).

\section{Table 7: Reasons for adopting sustainable soil management practices}

\begin{tabular}{lll} 
Reasons for adoption of SSM Practices & Frequency & Percent \\
\hline For sustainable production & 59 & 98.3 \\
For healthy soil and environment & 56 & 93.3 \\
Reduced side effects on health & 32 & 53.3 \\
Due to external support training, subsidy, etc & 59 & 98.3 \\
Due to minimization of cost & 48 & 80.0 \\
For higher yield & 60 & 100 \\
For higher price & 47 & 78.3
\end{tabular}

(Source: Field Survey, 2015) 
Rishi Ram Kattel \& Suraj Acharya / Sustainable Soil Management Practices: Adoption and Its Impact on Farm Income in Ramechhap District, Nepal

\section{Reasons for non-adoption of SSM practices}

Several reasons can be there for the non-adoption of SSM practices. All the respondents expressed lack of trainings and external support as the major reason for SSM nonadoption followed by increased workload on women and lack of labors due to migration of 5 percent and 1.7 percent respondents respectively (Table 8).

Table 8: Reasons for SSM practices non-adoption

\begin{tabular}{lll} 
Reasons for SSM practices non-adoption & Frequency & Percent \\
\hline Increased workload on women & 3 & 5.0 \\
Lack of labor due to migration & 1 & 1.7 \\
Lack of trainings and external support & 60 & 100
\end{tabular}

(Source: Field Survey, 2015)

\section{Impact of SSM practices on chemical fertilizers and pesticides use}

Study showed that use of chemical fertilizers was found decreased by majority of adopters ( 71.7 percent) and increased for 15 percent of adopters. For only 13 percent adopters it remained same after adoption of SSM practices. Whereas use of chemical pesticides was decreased by 73.3 percent for adopters it only increased by 10.0 percent and remained same for 16.7 percent after adoption of SSM practice.

\section{SWOT $^{5}$ Analysis of SSM practices}

Sustainable soil management (SSM) practices help to benefit farmers by reducing the cost of cultivation, increasing net return per unit area and also by reducing the harmful effects of over/misuse of chemical fertilizers and pesticides. In the long run excessive application of chemical fertilizers and pesticides with the population increment and initiation of commercial vegetable cultivation is causing the partial desertification in many pocket areas of agriculture (Awasthi, 2003). Manandhar (2004) suggested there is an urgent need for increasing the production and productivity, commercialization and competitiveness using the resource in sustainable manner. Thus, this research study was conducted to analyze the impact and economic significance of SSM practices in people's livelihoods. The strength, weakness, opportunities and threat of SSM practices from production and marketing perspective are presented in Table 9.

\section{Factors affecting the level of SSM practices adoption using Probit model}

Probit regression model focused on the 120 sampled farmers adopting sustainable soil management practices. Probit model was found to be correctly classified by 95.83 percent. For the interpretation of the model, marginal effects were driven from the regression coefficients (Table 10).

${ }^{5}$ Strength, Weakness, Opportunities and Threats

SIJMB | P-ISSN: 2313-1217 E-ISSN: 2410-1885 @ 201645 Sukkur Institute of Business Administration V.3, No.1 | Apr 16 
Rishi Ram Kattel \& Suraj Acharya / Sustainable Soil Management Practices: Adoption and Its Impact on Farm Income in Ramechhap District, Nepal

Table 9: SWOT analysis of SSM practices

\begin{tabular}{|c|c|c|}
\hline Themes & Strengths & Weaknesses \\
\hline $\begin{array}{l}\text { Vegetable } \\
\text { production }\end{array}$ & $\begin{array}{l}\text { Higher yield } \\
>\text { Sustainable production and } \\
\text { source of income for } \\
\text { longer period. } \\
>\quad \begin{array}{l}\text { Trainings availability and } \\
\text { capacity increased. }\end{array} \\
>\text { Increased soil fertility and } \\
\text { crop productivity. }\end{array}$ & $\begin{array}{l}\text { Unable to produce vegetables as } \\
\text { per efforts due to the lack of other } \\
\text { resources like irrigation. } \\
>\text { Occurrence of insect/pests and } \\
\text { disease. }\end{array}$ \\
\hline $\begin{array}{l}\text { Vegetable } \\
\text { marketing }\end{array}$ & $\begin{array}{l}\text { Easy access to } \\
\text { transportation and vehicles } \\
\text { for marketing }\end{array}$ & $\begin{array}{l}>\text { Lack of storage facilities. } \\
\text { Stalls for loading and unloading } \\
\text { of the products unavailability at } \\
\text { market. } \\
>\text { Perishable and delicate nature of } \\
\text { the vegetable products causing } \\
\text { damage during transportation. }\end{array}$ \\
\hline $\begin{array}{l}\text { Local } \\
\text { policy } \\
\text { framework }\end{array}$ & $\begin{array}{l}>\text { Political support to the } \\
\text { program and support from } \\
\text { every facet of the } \\
\text { community. } \\
15 \text { percent budget } \\
\text { allocated for the members } \\
\text { of SSMP through AFEC }{ }^{6} .\end{array}$ & $\begin{array}{l}\text { Budget leakage problems as } \\
\text { there is no direct access of budget } \\
\text { by the people. }\end{array}$ \\
\hline $\begin{array}{l}\text { GESI }^{7} \\
\text { aspects }\end{array}$ & $\begin{array}{l}\text { Strong and more women } \\
\text { participation/involvement } \\
\text { in the program. } \\
\text { Ethnic groups and minority } \\
\text { groups also actively and } \\
\text { highly involved in the } \\
\text { adoption. }\end{array}$ & $\begin{array}{l}\text { Workload on women. } \\
\text { Difficulty in inclusion of women } \\
\text { and socially backwarded } \\
\text { community as it is difficult to } \\
\text { convince them. }\end{array}$ \\
\hline Themes & Opportunities & Threats \\
\hline $\begin{array}{l}\text { Vegetable } \\
\text { production }\end{array}$ & $\begin{array}{l}>\text { Upliftment of the living } \\
\text { standard of the people. } \\
>\text { Livelihoods promotion of } \\
\text { the community. } \\
>\text { Quality and nutrition } \\
\text { awareness raised in the }\end{array}$ & $\begin{array}{l}\text { More supply of the vegetables } \\
\text { than demand in a small market. } \\
\text { Quantity focused by the farmers } \\
\text { than the quality which possesses } \\
\text { question for the sustainability of } \\
\text { the practices. }\end{array}$ \\
\hline
\end{tabular}
community.

${ }^{6}$ Agriculture, Forest, Environment Committee at local level

${ }^{7}$ Gender Equity and Social Inclusion

SIJMB | P-ISSN: 2313-1217 E-ISSN: 2410-1885 @ 201646 Sukkur Institute of Business Administration V.3, No.1 | Apr 16 
Rishi Ram Kattel \& Suraj Acharya / Sustainable Soil Management Practices: Adoption and Its Impact on Farm Income in Ramechhap District, Nepal

\begin{tabular}{|c|c|c|c|c|}
\hline & $D$ & $\begin{array}{l}\text { Good health and healthy } \\
\text { society. }\end{array}$ & & \\
\hline $\begin{array}{l}\text { Vegetable } \\
\text { marketing }\end{array}$ & 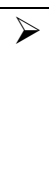 & $\begin{array}{l}\text { Products are also } \\
\text { transported outside village } \\
\text { and even outside the } \\
\text { district. }\end{array}$ & $D$ & $\begin{array}{l}\text { Price fluctuation. } \\
\text { Collection centers, storage and } \\
\text { stalls lacking. }\end{array}$ \\
\hline $\begin{array}{l}\text { Local } \\
\text { policy } \\
\text { framework }\end{array}$ & $>$ & $\begin{array}{l}\text { 15percent Budget } \\
\text { allocated in the program } \\
\text { through AFEC. } \\
\text { Agriculture sector is } \\
\text { focused at the village and } \\
\text { district level. }\end{array}$ & $D$ & $\begin{array}{l}\text { All the groups and people cannot } \\
\text { be included and some may feel } \\
\text { being isolated. }\end{array}$ \\
\hline $\begin{array}{l}\text { GESI } \\
\text { aspects }\end{array}$ & $\vec{P}$ & $\begin{array}{l}\text { Women empowerment. } \\
\text { Ethnic groups have raised } \\
\text { awareness. } \\
\text { Discrimination in the } \\
\text { community is reduced. }\end{array}$ & & $\begin{array}{l}\text { DAGs8 can be isolated and left } \\
\text { behind as compared to other } \\
\text { communities due to illiteracy and } \\
\text { their laggardness. }\end{array}$ \\
\hline
\end{tabular}

(Source: Field Survey, FGDs and KII, 2015)

Eleven variables namely age, gender, ethnicity, education of household headed, number of educated family members, number of economically active household members, outmigration, farm size and membership of other farming groups and organizations as well as farm income were applied to gauge the farmers' adoption behavior in SSM practices. Out of them, four variables were statistically significant for the level of adoption, they were; Type of family, education of household head, trainings received by household members and $\log$ farm income (i.e natural log transfer of farm income). More the family being nuclear, higher would be the probability of adoption level. The study revealed that, type of family was positively significant. Keeping other factors constant, if family is nuclear type, probability of adoption would increase by 76 percent. This might be due to the technology replacing the labour force in the agricultural activities. Although Hofferth (2003) reported that higher size of the household reduces the labour constraints and influence the adoption of new technology positively but on other hand technology replaces the labour force and increases the resource use efficiency. Thus nuclear family has less labour force and is more in need of technology than joint family with sufficient labour supply.

Higher education level of household head provides good ability to analyze and respond to new information much faster than their counterparts with lower education (Alam, 1965). Higher educated household head is expected to be more efficient and adopt new technologies in a shorter period of time than lesser educated one. The result showed that there is a negative relationship between status of education of household head and

${ }^{8}$ Disadvantage Groups

SIJMB | P-ISSN: 2313-1217 E-ISSN: 2410-1885 @ 201647 Sukkur Institute of Business Administration V.3, No.1 | Apr 16 
adoption of SSM practices. An increase in the level of the education lowers down the probability of technology being adopted. One year increase in education level of household head decreases the level of adoption by 9 per cent. This might be due to the fact that higher the level of education by household head, more is the chance of him/her being involved in other occupations like services, business etc. In our society farming is mainly done by the uneducated people traditionally, that is the old school thought which is still prevailing in the communities.

Contact with agriculture extension officers provide different information and increases the access of farmers to trainings which impacts farmer's capacity and they are expected to adopt new tools and technologies that suits them best. Trainings received (dummy) was positively significant to the adoption of SSM practices. Farmers receiving formal or informal training from either governmental or non-governmental organizations, the probability of adoption would increase by 60 percent. This can be credited to the improvement in skills, knowledge, awareness and realizing positive benefits from the adoption due to trainings. Shinghi, Fliegel, \& Kivlin (1973) reported positive relationship between social participation or trainings and adoption behaviour of farmers. Training helps to emphasize the message and improve the accuracy of technology packages through adoption (Table 10).

From the regression of the natural log transfer of farm income (i.e. log farm income), it was found that five independent variables were statistically significant for the farm income namely adoption, gender, family type, education level of household head and farm size. The regression model had good explanatory power at 1 percent level (Table 11). Farm income and adoption of technologies were found positively correlated. Study revealed that higher the adoption of technology higher was the farm income in the households. Result showed that if farmer adopts SSM practices at farm level, the farm income would be increased by 198 percent as compared to non-adopter which was found significantly significant at 1 percent level. This result was supported by Shinghi, Fliegel, \& Kivlin (1973) who reported the positive correlation between adoption and farm income.

Similarly Gender and farm size was found to be positively correlated with the farm income. Result also revealed that household head being male increases the farm income by 36 percent and 1 unit increase in farm size increases the farm income by 1 percent.

Result can be supported as household head being male generally increases the farm income which might be due to the fact that the male are involved in the heavy works in farm thus more work leads to more income. Alam (1965) stated the positive relationship between the household head being male and the farm income in Indian community.

SIJMB | P-ISSN: 2313-1217 E-ISSN: 2410-1885 @ 201648 Sukkur Institute of Business Administration V.3, No.1 | Apr 16 
Rishi Ram Kattel \& Suraj Acharya / Sustainable Soil Management Practices: Adoption and Its Impact on Farm Income in Ramechhap District, Nepal

Table 10: Factors influencing determinate of SSM practices adoption by farmers using Probit model

\begin{tabular}{|c|c|c|c|c|c|}
\hline Variable & Coefficient & 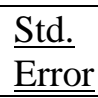 & $\underline{Z}$ & $\underline{\mathrm{P}>|\mathrm{Z}|}$ & $\underline{\mathrm{dy} / \mathrm{dx}}$ \\
\hline Age (in Year) & -0.0044 & 0.04 & -0.11 & 0.91 & -0.00069 \\
\hline Gender $($ Male $=1)$ & 0.22 & 0.81 & 0.27 & 0.78 & 0.03 \\
\hline Family (Nuclear type=1) & $3.24 *$ & 1.97 & 1.65 & 0.09 & $0.76^{*}$ \\
\hline Ethnicity $(\text { Higher caste }=1)^{9}$ & -0.10 & 1.51 & -0.07 & 0.94 & -0.01 \\
\hline Education (Year of schooling) & $-0.57 * *$ & 0.24 & -2.33 & 0.02 & $-0.09 * *$ \\
\hline $\begin{array}{l}\text { Educated (No. of educated } \\
\text { members in household) }\end{array}$ & 0.28 & 0.28 & 0.85 & 0.39 & 0.04 \\
\hline $\begin{array}{l}\text { Economically active } \mathrm{HH} \\
\text { member }\end{array}$ & -0.22 & 0.38 & -0.58 & 0.56 & -0.03 \\
\hline Migration $($ Yes=1) & -0.47 & 0.89 & -0.53 & 0.59 & -0.06 \\
\hline Farm size (in ha) & 0.01 & 0.05 & 0.26 & 0.79 & 0.0021 \\
\hline Trainings received $(\mathrm{Yes}=1)$ & $2.55 * *$ & 1.22 & 2.09 & 0.03 & $0.60 * *$ \\
\hline Membership (Yes=1) & 0.32 & 1.33 & 0.24 & 0.80 & 0.04 \\
\hline Number of observations & & & \multicolumn{3}{|l|}{120} \\
\hline LR $\operatorname{chi} 2(11)$ & & & \multicolumn{3}{|l|}{145.99} \\
\hline Pseudo $\mathrm{R}^{2}$ value & & & \multicolumn{3}{|l|}{0.8776} \\
\hline Log likelihood & & & \multicolumn{3}{|l|}{-10.18} \\
\hline Correctly classified model & & & \multicolumn{3}{|l|}{$95.83 \%$} \\
\hline Area under ROC curve & & & \multicolumn{3}{|l|}{0.9964} \\
\hline
\end{tabular}

Notes: $* * *, * *$ and $*$ indicate significant difference at $1 \%, 5 \%$ and $10 \%$ levels, respectively. dy/dx denotes marginal effects after Probit

Higher educated household head is expected to be more efficient and adopt new technologies in a shorter period of time than lesser educated one. The result showed that there is a significant positive relationship between level of education of household head and farm income. An increase in the level of the education increases the farm income in the family. One year increase in education level of household head increases the farm income by 11 percent. This might be due to the fact that higher the level of education by household head more is the chance of him/her adopting new technologies. This adoption of technology increases the efficiency of the farm production and decreases the cost of cultivation or farm production which ultimately increases the profit and thus farm income. Alam (1965) stated the positive relation between education level of the progressive farmers and the farm income.

The study revealed the negative relation between family type and the farm income. It showed that more the chance of family being a nuclear one lesser is the farm income in

${ }^{9}$ Brahmin, Chettri and Takuri are the higher castes in Nepal.

SIJMB | P-ISSN: 2313-1217 E-ISSN: 2410-1885 @ 201649 Sukkur Institute of Business Administration V.3, No.1 | Apr 16 
the household. From the result it was found that a family being a nuclear decreases the farm income by 50 percent. This might be due to the availability of the more labor force in the agricultural activities. Hofferth (2003) Reported that higher size of the household reduces the labor constraints and influence the adoption of new technology positively which ultimately helps in increasing the farm income (Table 11).

Table 11: Impact of SSM practices adoption on farm income (NRs. in natural log)

\begin{tabular}{|c|c|c|c|c|}
\hline Variable & $\underline{\text { Coefficient }}$ & $\underline{\mathrm{T} \text { value }}$ & $\underline{\mathrm{P}>|\mathrm{Z}|}$ & $\begin{array}{l}\text { Std. } \\
\text { error }\end{array}$ \\
\hline SSM Adoption (Yes=1) & $1.98 * * *$ & 7.71 & 0.000 & $\overline{0.25}$ \\
\hline Age of the respondent (in Year) & -0.0043 & -0.40 & 0.690 & 0.01 \\
\hline Gender $($ Male $=1)$ & $0.36 *$ & 1.67 & 0.098 & 0.22 \\
\hline Family (Nuclear type=1) & $-0.50 *$ & -1.86 & 0.066 & 0.27 \\
\hline Ethnicity (Higher caste=1) & 0.33 & 1.31 & 0.193 & 0.25 \\
\hline Education (Year of schooling) & $0.11 * *$ & 2.23 & 0.028 & 0.05 \\
\hline $\begin{array}{l}\text { Educated (No. of educated members in } \\
\text { household) }\end{array}$ & 0.0028 & 0.04 & 0.971 & 0.07 \\
\hline Economically active HH members & -0.024 & -0.32 & 0.751 & 0.07 \\
\hline Migration ( Yes=1) & 0.30 & 1.26 & 0.211 & 0.24 \\
\hline Farm size (in hectare) & $0.01 *$ & 1.69 & 0.094 & 0.0077 \\
\hline Trainings received $(\mathrm{Yes}=1)$ & -0.21 & -0.86 & 0.392 & 0.25 \\
\hline Membership (Yes=1) & -0.34 & -0.72 & 0.473 & 0.47 \\
\hline
\end{tabular}

\section{Summary Statistics:}

$\mathrm{N}$

R-Squared value

Adjusted R-Squared value

$\mathrm{F}(12,107)$ value

$* *$

Note: $* * *, * *$ and $*$ indicate significant difference at $1 \%, 5 \%$ and $10 \%$ levels, respectively.

\section{Conclusion}

Sustainable soil management is an advantageous practice for the vegetable growing farmers which promotes sustainable agriculture and discourages inorganic farming. It helps to benefit farmers by reducing the cost of cultivation, increasing net return per unit area and also by reducing the harmful effects of over/misuse of chemical fertilizers and pesticides. SSM practices adoption has played a major role in livelihood promotion and economic upliftment of the vegetable growing farmers.

From the study it was found that lack of trainings and external support along with the lack of local resources specially irrigation problem was the major reason for non- 
adoption of SSM practices. Probit model showed that, three variables were statistically significant for the level of adoption, they were; type of family, education of household head and trainings received by household members. From the regression of the farm income it was found that five independent variables were statistically significant for the farm income namely adoption, gender, family type, education level of household head and farm size. Farm income and adoption of technologies were found positively correlated. Study revealed that higher the adoption of technology higher was the farm income in the households. Result showed that if farmer adopts SSM practices at farm level, the farm income would be increased by 198 percent as compared to non-adopter which was found significantly significant at 1 percent level.

These SSM practices are easily accessible in local conditions, cost effective and help to maintain soil health and fertility as well as increase farm income. Study also revealed that adopters were found more food secured than non-adopters. It was also observed that the adopters had more access to membership in different farming groups and organizations, trainings and attended more educational meetings than non-adopters in recent times. Adopters also had more access to information and technology than nonadopters.

Realizing the potential and significance of the sustainable soil management practices and its contribution to household food security, it is necessary to promote these practices in different parts of the country.

\section{Acknowledgments}

This research was financially supported by Sustainable Soil Management Programme (SSMP)/Helvetas Swiss Cooperation. We would like to acknowledge the Directorate of Research (DOR), Agriculture and Forestry University (AFU) and Department of Agricultural and Agribusiness Management, Rampur, Chitwan Nepal. But not least, we are deeply indebted to the households, communities and line agencies in research areas, who are too numerous to mention individually, but without whose cooperation this study would not have been possible.

\section{References}

AEC. (2006). Off-season vegetables. Teku, Kathmandu, Nepal: Agro Enterprise Centre/Federation of Nepalese Chamber of Commerce and Industry.

Cook, R., Norris, K., \& Pickel, C. (1989). Economic Comparison of Organic and Conventional Production Methods for Fruits and Vegetables. Organic Vegetable Farming. Kearney Agricultural Center. University of California.

Cromwell, E., \& Winpenny, J. (1993). Does economic reform harm the environment? A review of structural adjustment in Malawi. Journal of International Development, 5(6), 623-649.

SIJMB | P-ISSN: 2313-1217 E-ISSN: 2410-1885 @ 201651 Sukkur Institute of Business Administration V.3, No.1 | Apr 16 
Rishi Ram Kattel \& Suraj Acharya / Sustainable Soil Management Practices: Adoption and Its Impact on Farm Income in Ramechhap District, Nepal

Diary, K. (2014). Harihar bhawan Kathamandu: Agriculture information and communication center.

Feder, G., Just, R. E., \& Zilberman, D. (1985). Adoption of agricultural innovations in developing countries: A survey. Economic development and cultural change, 33(2), 255-298.

Flaig, W. (1975). Specific effects of soil organic matter on the potential of soil productivity. FAO Bulletin, 27, 31-69.

Harden, C. P. (2001). Soil erosion and sustainable mountain development: experiments, observations, and recommendations from the Ecuadorian Andes. Mountain Research and Development, 21(1), 77-83.

Joshi, B., \& Ghimire, S. (1996). Livestock and soil fertility: a double bind. ILEIA Newsletter, 12(1), 18.

Leu, A. (2004). Organic Agriculture Can Save the World. Well Being Journal, 13(2).

Maheswarappa, H., Nanjappa, H., \& Hegde, M. (2015). Influence of planting material, plant population and organic manures on galangal (Kaempferia galanga L.) grown as intercrop in coconut (Cocos nucifera L.) garden. Journal of Spices and Aromatic Crops, 8(1).

Mann, C. K. (1978). Packages of practices: A step at a time with clusters. Studies in development, $21,73-81$.

Mannion, A. M. (1995). Agriculture and environmental change: temporal and spatial dimensions: John Wiley \& Sons.

Musser, W. N., Wetzstein, M. E., Reece, S. Y., Varca, P. E., Edwards, D. M., \& Douce, G. K. (1986). YBeliefs of Farmers and Adoption of Integrated Pest Managemeny. Agricultural economics research, 38(1), 34.

Olson, K. D., Langley, J., \& Heady, E. O. (1982). Widespread adoption of organic farming practices: Estimated impacts on US agriculture. Journal of Soil and Water Conservation, 37(1), 41-45.

Prasain, S. (2011). Nepal producers veggeies worth NPRS 45 billion annually.

Rasul, G., \& Thapa, G. B. (2003). Sustainability analysis of ecological and conventional agricultural systems in Bangladesh. World development, 31(10), 1721-1741.

Rogers, E. M. (2003). Diffusion of Innovations: Simon and Schuster.

Schjønning, P., Christensen, B. T., \& Carstensen, B. (1994). Physical and chemical properties of a sandy loam receiving animal manure, mineral fertilizer or no fertilizer for 90 years. European Journal of Soil Science, 45(3), 257-268.

Scialabba, N. (2006). Organic Agriculture Perspectives. Paper presented at the Conference on Supporting the Diversification of Exports in the Latin America and Caribbean Region through the Development of Organic Agriculture. Portof-Spain.

Scofield, A. (1986). Organic farming - the origin of the name. Biological Agriculture \& Horticulture, 4(1), 1-5.

Shrestha, B., Maskey, S., Shrestha, R., Tripathi, B., Khadga, Y., Munankarmy, R., . . . Shrestha, S. (2000). Soil Fertility Management: Farmers Practices and Perceptions in the Hills of Nepal. Lumle technical paper(2000/4).

SIJMB | P-ISSN: 2313-1217 E-ISSN: 2410-1885 @ 201652 Sukkur Institute of Business Administration V.3, No.1 | Apr 16 
Rishi Ram Kattel \& Suraj Acharya / Sustainable Soil Management Practices: Adoption and Its Impact on Farm Income in Ramechhap District, Nepal

Sthapit, B., Gurung, G., Gautam, M., Paudel, D., Gurung, D., \& Ghale, N. (1988). Traditional Methods of Sustaining Crop Productivity in the Lower Hills (300700 m): Problems and Potentials. Technical Paper(88/9).

Subedi, K., Gurung, G., Paudel, D., Gurung, K., Gurung, D., \& Gurung, J. (1989). Traditional methods of maintaining soil fertility in the mid and high hills (12002100m as1) of the Western development region of Nepal (Kaski and Lamjung Districts) Problems and potentials.

Tamang, D. (1992). Indigenous Soil Fertility Management in the Hills of Nepal. Lessons from an East-West Transect. HMG ministry of Agriculture Win rock International Research Report(19).

Thapa, G. B. (1996). Land use, land management and environment in a subsistence mountain economy in Nepal. Agriculture, ecosystems \& environment, 57(1), 57-71.

SIJMB | P-ISSN: 2313-1217 E-ISSN: 2410-1885 @ 201653 Sukkur Institute of Business Administration V.3, No.1 | Apr 16 